\title{
The Effect of the Coach-Athlete Relationship on Passion for Sports: The Case of Male Handball Players in Super League
}

\author{
Sevim Güllü \\ Correspondence: Istanbul University-Cerrahpasa, Faculty of Sport Sciences, Istanbul, Turkey. \\ E-mail:sevim.gullu@istanbul.edu.tr \\ Received: October 31, 2018 \\ Accepted: November 29, 2018 Online Published: December 6, 2018 \\ doi:10.11114/jets.v7i1.3724 \\ URL: https://doi.org/10.11114/jets.v7i1.3724
}

\begin{abstract}
The purpose of this study is to reveal out the relationship between the team players' perceived coach-athlete relationship and their passion in sports. This is a research carried out with sectional screening model. The study group consisted of 200 male handball players in super league in Turkey. Participants were asked questions with demographic information to obtain personal information. Additionally, 11 question "Coach-Athlete Relationship Scale" developed by Jowett \& Ntoumanis (2004) and adapted to Turkish by Altıntaş et al. (2012) and 12 question "Athlete Passion Scale" developed by Vallerand et al. (2003) and adapted to Turkish by Kelecek \& Aşçı (2013) was applied. To evaluate the obtained data SPSS 20 package program was used and percentage (\%), frequency (f), Kruskal Wallis test, correlation analysis, and regression analysis were conducted. There was a positive relationship between the coach-athlete relationship and its sub-dimensions of commitment, closeness and complementarity and also between the passion for sports and its sub-dimensions of harmonious passion and obsessive passion. Besides, the regression analysis has shown that the coach-athlete relationship has a relatively high impact on the passion for sports. In other words, as the effectiveness and quality of the coach-athlete relationship increase, so does "passion", which is one of the most important motivation sources for the athletes. At the end of our research it was found that, the coach-athlete relationship was at high level. As a result, there is a relationship between coach-athlete relationship and sport passion.
\end{abstract}

Keywords: coach-athlete relationship, leadership, sports passion, handball

\section{Introduction}

The coach is one of the most important figures in the career of an amateur or a professional athlete (Short \& Short, 2005:529). Such that, the quality of the relationship and communication between the coach and athlete directly affects the success of the athlete. During training for competitions, they spend nearly the entire day together except for the sleeping hours, which enables them to establish rapport and get to know each other better. Indeed, the interaction occuring during this period directly contributes to mutual success.

Several researches exploring the relationship between the behaviours of the coach and motivation of the athlete, emphasizes the importance of the coach's role (Vallerand \& Losier 1999; Hollembeak \& Amorose 2005; Vallerand \& Rousseau 2001; Amorose \& Anderson-Butcher 2007; Sarrazin, Guillet, \& Cury 2001; McLean \& Mallett, 2012). Behind all great teams and athletes, stands a coach supporting them in reaching their goals and passions (Voss, 2000:22). The coach teaches the athletes the rules of sports, gives them tactical training, helps them acquire agility and practicality. Coaches transfer their experience and knowledge to the athletes, and they also guide them through their way of communication with the other athletes in the team and with the competitors. They make efforts to have the athletes work in unity with the team (Güllü \& Şahin, 2016:864). The role of the coach in sports has now gained a corporate identity. For instance; a football team consists of 11 players and all the people with different specialty areas, from the substitute player to the doctor and from the masseur to the coach serve together to help the team reach success. So, it is important that they all work in harmony with each other. Here, the coach is the leader determining the dynamics of the team (Karakoç et al., 2011:322, 323,329).

As pointed out by Kassing \& Infante (1999); coaches influence the performance, skills, motivation (Black \& Weiss, 1992) and self-confidence of the athletes (Sinclair \& Vealey, 1989) and their sense of competence (Horn, 1985). On the other hand, it is also possible that coaches do not have positive influence (Weinstein, Smith \& Weisenthal, 1995) and coach does not affect all players in the same way, indeed (Sinclair \& Vealey, 1989). Coach is the person who knows and 
behaves according to the differences of athletes (Yaşar ve Sunay, 2018). Due to the fact that the guiding behaviours, words and messages of coaches are important for the athletes (Güllü \& Şahin, 2016:865), they should develop appropriate communication style and behaviour. The coach is the person who teaches the athletes to follow the rules of fair play (Arıpınar \& Donuk, 2011:101). Such that, a coach should even take care of his physical appearance in order to serve as a model for the athletes (Şahin, 2011).

An individual's being successful in all fields of life directly depends on his/her ability to use communication skills appropriately (Göksel et al., 2016:1441). The quality of the interaction between the coach and the athlete is very important for the success of the athlete (Donuk, 2007). The coach-athlete relationship is a concept that is used to describe the interaction between the coach and athlete with respect to their feelings, thoughts and behaviours (Jowett \& Ntoumanis, 2004:255). In order for the athletes to display a superior performance, the athletes need to establish a good relationship with their coaches. Establishment of a good relationship depends on the quality of communication. As pointed out by Altıntaş et al. (2012:120), communication is not a one-way interaction, it is reciprocal and two-way. This process, which has an important place in human life, also has a significant role in sports. In sports, the relationship between the athlete and the coach is important both for the psychosocial and physical development of the athletes. A positive coach-athlete relationship developed in a context environments involving positive communication processes both enhances the motivation and satisfaction of the athletes and ensures a suitable environment for the development of the skills of the athletes.

It is generally accepted that the coach's leadership style plays an important role in the success of the team in sports fields (Filiz \& Demirhan, 2017:1). Such that, Çalışkan (2011) assessed the coach-athlete relationship for football players using the leader-member exchange (LMX) theory. This theory emphasizes the quality of the relationship between the leader (coach) and the group member (athlete). The leader develops a different level of relationship with each member, depending on the characteristics of the member (Çalışkan, 2011; Yildiz, 2011) Caliskan (2015) then adapted the coach-athlete relationship scale based on the leader-member exchange theory.

As the competitiveness of the athletes and their success in sports increase, the time they spend with their coach increases, as well. While the coach-athlete relationship changes depending on the demographic variables such as age and gender (Ashley \& Gretchen, 2009: 228,229), there are researches arguing that it is one of the most important and influential relationships particularly in the success of young athletes (Cumming et al., 2007; Fry \& Newton, 2003; Pelletieretal., 2002; Sarrizin et al., 2002; Fry \& Gano-Overway, 2010; Ashley \& Gretchen, 2009). Such that, as much as the parents and the teachers, the coach can be a very important motivation source for the child athletes (Kegan et al., 2009; cited by Kolayiş et al, 2017).

The relationship between the coach and athlete is described based on the sub-dimensions of commitment, complementarity and closeness (Jowett, 2007; Jowett, Paull, Pensgaard, Hoegmo, \& Riise, 2005; Adie \& Jowett, 2010; Jowett \& Cockerill, 2002). Closeness reflects the emotional tone of the relationship (Jowett, 2008). It is used to express the degree of appreciation, trust, respect and appreciation of between the coach and the athlete. Commitment expresses the coaches' and athletes' intention and desire to continue their relationship without any expectations. Complementarity, on the other hand, can be defined as the cooperation between the coach and the athlete. They both want to win, they adopt a kind and friendly attitude each other towards each other and take responsibilities, which indicate the complementarity dimension of the behavioral features (Jowett, 2005, 2007; Adie \& Jowett, 2010).

For centuries, the meaning of 'passion' has attracted the attention of several disciplines, particularly including philosophy (Paradis et al., 2013:493). Researchers aiming to describe the behaviours and feelings of the individual in sports context, his/her reason for participating or staying in this context and the degree such reasons influence the individual, have recently started to study the concept of passion (Kelecek \& Aş̧̧ı, 2013:81). Passion is important for an athlete to have high motivation (Gustafsson et al., 2011) and is one of the most significant psychological factors allowing him/her to reach utmost success (Demirci \& Çepikkurt, 2018).

Vallerand et al. (2003), pointed out the fact that when individuals deal with an activity they are fond of and internalize it, such activity turns into a passion. Passion is defined as the strong tendency of an individuals toward an activity he/she likes and/or loves, cares about and spends time and energy on. Passion plays a significant role in people's daily lives, in their participation to an activity and sustaining such participation (Vallerand, 2008; Vallerand \& Houlfort, 2003; Vallerand \& Miquelon, 2007; Vallerand et al.., 2003; Vallerand et al., 2008).

Vallerand et al. (2003) developed a 2-dimensions model of passion consisting of the sub-dimensions of harmonious passion and obsessive passion. Harmonious passion is defined as choosing an activity freely and willingly without any external effect and internalizing such activity. On the other hand, obsessive passion is defined as one's internalization of an activity in a controlled manner depending on personal or inter-personal pressure or phenomena (social acceptance, self-respect); the individual feels obliged to participate in the activity through personal or inter-personal pressure and a 
controlled internalization process takes place. While participating in the activity brings along social acceptance and self-respect, the individual has negative feelings, such as guilt, sorrow and shame when he/she doesn't participate. Unlike harmoniously passionate people, obsessively passionate people are stricter and more insistent due to the controller nature of obsessive passion; they are furious, anxious and have difficulty in concentration (Paradis et al., 2013:493; Kelecek \& Aşç1, 2013:81).

The purpose of this study is to reveal out the the level of relationship between the team players' perceived coach-athlete relationship and their passion for sports.

\section{Methodology}

\section{Research model}

The research is designed in the cross-sectional screening model.

\section{Participants}

The study group consists of 200 male handball players in super league in Turkey. The research is based on willingness. The participants were informed about the purpose and subject of the research and data were collected later.

\section{Data Collection Tools}

In order to get personal information, the participants were asked questions related to demographic features. The researcher also used the 11-question "Coach-Athlete Relationship Scale" developed by Jowett and Ntoumanis (2004) which consists of the sub-dimensions of "closeness", "commitment" and "complementarity", validity and reliability of the Turkish version of which were comfirmed by Altıntaş et al., (2012). The 12-question "Athlete's Passion Scale" developed by Vallerand et al., (2003), which was adapted Turkish by Kelecek \& Aş̧ı (2013) and which consists of the sub-dimensions of "harmonious passion" and "obsessive passion". The survey questions in the research were prepared in 7-point Likert scale. 1 point was given for the statement "I strongly disagree" and 7 points were given for the statement "I strongly agree".

The reliability analysis was performed for this research also.

\section{Data Analysis}

SPSS 20 package software was used for the assessment of the data obtained. Percentage (\%) and frequency (f) methods among the descriptive statistical methods were used to determine the distribution of the personal data of the participants. The Kolmogorov-Smirnov Test for normality was used to determine whether the data displayed a normal distribution. Once it was found that the data were suitable for non-parametric test conditions, the Mann Whitney U test was applied for the two-factor variables in order to determine significant differences and the Kruskall Wallis test was applied for the variables with three or more factors. The level of significance was accepted as $\mathrm{p}<0.05$. Furthermore, correlation analysis was performed in order to prove the presence of a statistically significant relationship between the two scales. Regression analysis was performed to test the effect of the Coach-Athlete relationship on the participants' Passion for Sports.

\section{Research Hypotheses}

The following hypotheses will be tested within the scope of our research.

H1: There is a positive relationship between the Coach-Athlete relationship variable and the Passion for Sports variable.

H2: There is a positive relationship between the Coach-Athlete relationship variable and the Harmonious Passion sub-dimension of the Passion for Sports.

H3: There is a positive relationship between the Coach-Athlete relationship variable and the Obsessive Passion sub-dimension of the Passion for Sports.

H4: There is a positive relationship between the closeness sub-dimension of the Coach-Athlete relationship variable and the Passion for Sports.

H5: There is a positive relationship between the closeness sub-dimension of the Coach-Athlete relationship variable and the harmonious passion sub-dimension of the Passion for Sports.

H6: There is a positive relationship between the closeness sub-dimension of the Coach-Athlete relationship variable and the obsessive passion sub-dimension.

H7: There is a positive relationship between the commitment sub-dimension of the Coach-Athlete relationship variable and the Passion for Sports.

H8: There is a positive relationship between the commitment sub-dimension of the Coach-Athlete relationship variable 
and the harmonious passion sub-dimension.

H9: There is a positive relationship between the commitment sub-dimension of the Coach-Athlete relationship variable and the obsessive passion sub-dimension.

H10: There is a positive relationship between the complementarity sub-dimension of the Coach-Athlete relationship variable and the Passion for Sports.

H11: There is a positive relationship between the complementarity sub-dimension of the Coach-Athlete relationship variable and the harmonious passion sub-dimension.

H12: There is a positive relationship between the complementarity sub-dimension of the Coach-Athlete relationship variable and the obsessive passion sub-dimension.

H13: The Coach-Athlete relationship has effect on the passion for sports.

\section{Findings and Results}

Table 1. Scale Points

\begin{tabular}{ccccccc}
\hline & $\mathrm{n}$ & Min & Max & mean & $\begin{array}{c}\text { standard } \\
\text { deviation }\end{array}$ & $\begin{array}{c}\text { Cronbach } \\
\text { alpha }\end{array}$ \\
\hline The Coach-Athlete & 200 & 3.180 & 7.000 & 5.934 & .830 & 0.870 \\
$\begin{array}{c}\text { Relationship Scale } \\
\text { Sub-Dimension of } \\
\begin{array}{c}\text { Commitment } \\
\text { Sub-Dimension of }\end{array}\end{array}$ & 200 & 2.750 & 7.000 & 6.134 & .841 & 0.830 \\
$\begin{array}{c}\text { Closeness } \\
\text { Sub-Dimension of } \\
\text { complementarity }\end{array}$ & 200 & 1.330 & 7.000 & 5.851 & 1.151 & 0.710 \\
$\begin{array}{c}\text { Athlete's Passion } \\
\begin{array}{c}\text { Scale } \\
\text { Sub-Dimension of }\end{array}\end{array}$ & 200 & 2.800 & 7.000 & 5.797 & .853 & 0.690 \\
$\begin{array}{c}\text { Harmonious Passion } \\
\text { Sub-Dimension of }\end{array}$ & 200 & 2.330 & 7.000 & 5.697 & .938 & 0.770 \\
Obsessive Passion & 200 & 2.170 & 6.830 & 4.850 & 1.093 & 0.740 \\
\hline
\end{tabular}

Table 1 shows that there is a high rate of participation to both scales and their sub-dimensions. The Cronbach Alpha values are high for both scales and their sub-dimensions.

It is observed in the Coach-Athlete Relationship Scale that, the highest agreement is with the statement "I respect my coach" ( $\mathrm{X}=6,380)$ and the lowest agreement is with the statement "I behave my coach in a friendly manner during training" ( $\overline{\mathrm{X}}=5,510)$ It is observed in the Passion for Sports Scale that, the highest agreement is with the statement "This activity would allow me to have different experiences" $(X=5,970)$ and the lowest agreement is with the

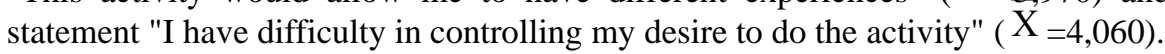

Table 2. Demographic Features of the Participants

\begin{tabular}{|c|c|c|c|}
\hline & & $\mathrm{n}$ & $\%$ \\
\hline \multirow[b]{4}{*}{ Age } & Age 20 and under & 36 & $18 \%$ \\
\hline & Ages 21-25 & 78 & $39 \%$ \\
\hline & Ages 26-30 & 69 & $34.5 \%$ \\
\hline & Age 31 and over & 17 & $8.5 \%$ \\
\hline \multirow{3}{*}{ Educational Background } & High school graduate & 20 & $10 \%$ \\
\hline & University Student & 174 & $87 \%$ \\
\hline & University graduate & 6 & $3 \%$ \\
\hline \multirow{3}{*}{ How long have you been playing handball? } & For 10 years or less & 58 & $29 \%$ \\
\hline & For $11-15$ years & 76 & $38 \%$ \\
\hline & For 16 years or more & 66 & $33 \%$ \\
\hline \multirow{3}{*}{ How long have you been in your current sports club? } & For $1-5$ years & 140 & $70 \%$ \\
\hline & For 6-10 years & 47 & $23.5 \%$ \\
\hline & For $11-15$ years & 13 & $6.5 \%$ \\
\hline \multirow{3}{*}{ How long have you been training with your current coach? } & For 1-5 years & 149 & $74.5 \%$ \\
\hline & For 6-10 years & 38 & $19 \%$ \\
\hline & For $11-15$ years & 13 & \\
\hline
\end{tabular}

According to Table $2 ; 18 \%$ of the participants are of age 25 or under, $39 \%$ of them are between ages $21-25,34.5 \%$ of them are between ages $26-30,8.5 \%$ of them are of age 31 or over, $10 \%$ of them are high school graduates, $87 \%$ of them 
are university students and 3\% of them are university graduates. $29 \%$ of the participants have been playing handball for 10 years or less, $38 \%$ of them have been playing for 11-15 years and 33\% of them have been playing for 16 years or more. On the other hand; while $70 \%$ of them have been playing handball in their current club for $1-5$ years, $74.5 \%$ of them have been training with their current coach for the same time period; while $23.5 \%$ of them have been playing handball in their current club for 6-10 years, $19 \%$ of them have been training with their current coach for the same time period; and $6.5 \%$ of them have been playing in their current club and training with their current coach for 11-15 years.

Results of the the Kolmogorov Smirnov test performed to find out whether the coach-athlete relationship scale and its sub-dimensions and the athlete's passion scale and its sub-dimensions displayed a normal distribution, showed that, none of them displayed a normal distribution $(\mathrm{p}<0.05)$. Therefore; non-parametric tests should be applied in order to find out whether the demographic variables produce a significant difference in the coach-athlete relationship scale and its sub-dimensions and the athlete's passion scale and its sub-dimensions. The Kruskal-Wallis test was used in this research as the variables to be involved in the analysis consisted of three or more factors. The results are presented below:

Table 3. Athlete's Passion and the Sub-dimensions Levels Related to the Ages of the Participants

\begin{tabular}{|c|c|c|c|c|c|c|}
\hline \multirow[b]{2}{*}{ Age } & \multicolumn{4}{|c|}{ Mean } & \multirow[b]{2}{*}{$\chi^{2}$} & \multirow[b]{2}{*}{$p$} \\
\hline & & $\mathrm{N}$ & Rank & df & & \\
\hline \multirow[t]{5}{*}{ Athlete's Passion Scale } & Age 20 and under & 36 & 86.75 & & & \\
\hline & Ages 21-25 & 78 & 89.65 & & & \\
\hline & Ages $26-30$ & 69 & 102.33 & 3 & 2.257 & 0.431 \\
\hline & Age 31 and over & 17 & 88.63 & & & \\
\hline & Total & 200 & & & & \\
\hline Sub-Dimension of Harmonious & Age 20 and under & 36 & 78.94 & & & \\
\hline \multirow[t]{4}{*}{ Passion } & Ages 21-25 & 78 & 94.45 & & & \\
\hline & Ages 26-30 & 69 & 101.85 & 3 & 4.497 & 0.213 \\
\hline & Age 31 and over & 17 & 83.73 & & & \\
\hline & Total & 200 & & & & \\
\hline \multirow[t]{5}{*}{ Sub-Dimension of Obsessive Passion } & Age 20 and under & 36 & 95.45 & & & \\
\hline & Ages $21-25$ & 78 & 86.25 & & & \\
\hline & Ages $26-30$ & 69 & 102.04 & 3 & 3.185 & 0.364 \\
\hline & Age 31 and over & 17 & 88.10 & & & \\
\hline & Total & 200 & & & & \\
\hline
\end{tabular}

Table 3 presents the results of the Kruskal-Wallis test related to the ages of the research participants. According to the results of analysis, there is no significant difference depending on the ages, with respect to athlete's passion $\left(X^{2}(3)=2.257 ; p>0.05\right)$, sub-dimension of harmonious passion $\left(X^{2}(3)=4.497 ; p>0.05\right)$, sub-dimension of obsessive passion $\left(X^{2}(3)=3.185 ; p>0.05\right)$. Also, there is no significant difference related to the ages of the research participants according to the coach-athlete relationship and its sub-dimensions ( $\mathrm{p}>0.05)$.

Table 4. Athlete's Passion and the Sub-dimensions Levels Related to the Years the Participants Have Been Playing Handball for

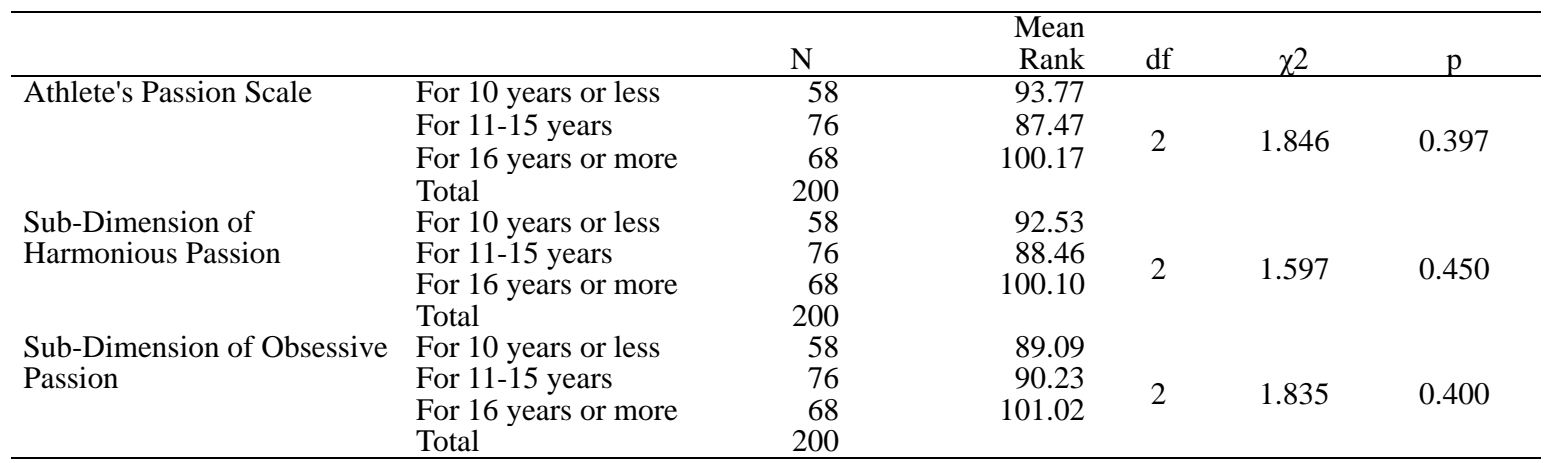

Table 4 presents the Kruskal-Wallis test results related to the time period research participants have been playing handball. According to the results of analysis, there is no significant difference related to the years the athletes have been playing handball for, with respect to athlete's passion $\left(\mathrm{X}^{2}(2)=1.846 ; \mathrm{p}>0.05\right)$, sub-dimension of harmonious passion $\left(X^{2}(2)=1.597 ; p>0.05\right)$, sub-dimension of obsessive passion $\left(X^{2}(2)=1.835 ; p>0.05\right)$. Also, there is no significant difference related to the "Years the Participants Have Been Playing Handball for" of the research participants according to the coach-athlete relationship and its sub-dimensions ( $\mathrm{p}>0.05)$.

It couldn't be analysed whether the variables of educational background of the participants, the years they have played in their current clubs and with their current coaches differed depending on the coach-athlete relationship and athlete's passion, due to the fact that there were numerous differences among the groups. 
Table 5. The Relationship between the Coach-Athlete Relationship and Athlete's Passion

\begin{tabular}{|c|c|c|c|c|c|c|c|c|}
\hline & & 1 & 2 & 3 & 4 & 5 & 6 & 7 \\
\hline 1-Passion for Sports & $\mathrm{r}$ & 1.000 & & & & & & \\
\hline & $\mathrm{p}$ & & & & & & & \\
\hline \multirow{4}{*}{ 2- Sub-Dimension of Harmonious Passion } & $\mathrm{n}$ & 186 & & & & & & \\
\hline & $\mathrm{r}$ & $.708^{* \pi *}$ & 1.000 & & & & & \\
\hline & $\mathrm{p}$ & .000 & & & & & & \\
\hline & $\mathrm{N}$ & 186 & 186 & & & & & \\
\hline \multirow[t]{3}{*}{ 3- Sub-Dimension of Obsessive Passion } & $\mathrm{r}$ & $.831^{* *}$ & $.299^{* *}$ & 1.000 & & & & \\
\hline & $\mathrm{p}$ & .000 & .000 & & & & & \\
\hline & $\mathrm{n}$ & 186 & 186 & 186 & & & & \\
\hline \multirow[t]{3}{*}{ 4- The Coach-Athlete Relationship } & $\mathrm{r}$ & $.381^{* 4}$ & $.266^{* *}$ & $.305^{\mathrm{k}}$ & 1.000 & & & \\
\hline & $\mathrm{p}$ & .000 & .000 & .000 & & & & \\
\hline & $\mathrm{n}$ & 186 & 186 & 186 & 186 & & & \\
\hline \multirow{2}{*}{ 5- Sub-Dimension of Closeness } & $\begin{array}{l}\mathrm{r} \\
\mathrm{p}\end{array}$ & $\begin{array}{l}.329 \\
000\end{array}$ & $.357^{\prime \prime}$ & $.145^{\prime \prime}$ & .768 & 1.000 & & \\
\hline & $\mathrm{n}$ & 186 & 186 & $\begin{array}{l}.040 \\
186\end{array}$ & 186 & 186 & & \\
\hline \multirow[t]{3}{*}{ 6- Sub-Dimension of Commitment } & $\mathrm{r}$ & $.465^{\pi *}$ & $.315^{* \pi}$ & $.361^{* \pi}$ & $.822^{\pi *}$ & $.569^{\pi * \pi}$ & 1.000 & \\
\hline & $\mathrm{p}$ & .000 & .000 & .000 & .000 & .000 & & \\
\hline & $\mathrm{n}$ & 186 & 186 & 186 & 186 & 186 & 186 & \\
\hline \multirow[t]{3}{*}{ 7- Sub-Dimension of complementarity } & $\mathrm{r}$ & $.330^{* *}$ & $.185^{\pi}$ & $.291^{* \pi *}$ & $.870^{* * *}$ & $.537^{\pi *}$ & $.616^{\pi * \pi}$ & 1.000 \\
\hline & $\mathrm{p}$ & .000 & 012 & .000 & .000 & .000 & .000 & \\
\hline & $\mathrm{n}$ & 186 & 186 & 186 & 186 & 186 & 186 & 186 \\
\hline
\end{tabular}

Correlation is significant at the 0.01 level (2-tailed).**

Correlation is significant at the 0.05 level (2-tailed).*

According to the results of the Correlation analysis presented in Table 5, there is a positive and low-level relationship between athlete's passion and the coach-athlete relationship ( $\mathrm{r}=0.381$ ), a positive and low-level relationship with the sub-dimension of closeness ( $\mathrm{r}=0.329)$, a positive and moderate-level relationship with the sub-dimension of commitment $(\mathrm{r}=0.465)$ and a positive and low-level relationship with the sub-dimension of complementarity $(\mathrm{r}=0.330)$. It is proven that; there is a positive and low-level $(\mathrm{r}=0.266)$ relationship between the coach-athlete relationship and the sub-dimension of harmonious passion; a positive and low-level $(\mathrm{r}=0.305)$ relationship between the coach-athlete relationship and the sub-dimension of obsessive passion; a positive and low-level ( $\mathrm{r}=0.357)$ relationship between the sub dimension of closeness and sub-dimension of harmonious passion; a positive and low-level $(\mathrm{r}=0.145)$ relationship between the sub-dimension of closeness and sub-dimension of obsessive passion; a positive and low-level $(r=0.315)$ relationship between the sub-dimension of commitment and harmonious passion; a positive and low-level $(\mathrm{r}=0.361)$ relationship between the sub-dimension of commitment and obsessive passion; a positive and low-level $(\mathrm{r}=0.185)$ relationship between the sub-dimension of complementarity and harmonious passion; a positive and low-level $(\mathrm{r}=0.291)$ relationship between the sub-dimension of complementarity and obsessive passion. These relationships are statistically significant, as well $(\mathrm{p}<0.05)$.

In conclusion, there is a positive relationship between the coach-athlete relationship and its sub-dimensions and the athlete's passion and its sub-dimensions.

Table 6. The Effect of the Coach-Athlete Relationship on the Passion for Sports

\begin{tabular}{|c|c|c|c|c|c|c|}
\hline \multicolumn{7}{|c|}{ Model Summary-1 } \\
\hline $\mathbf{R}$ & R Square & & Adjusted R Square & Standard Error of the Estimate & Standardized $\beta$ & Coefficient \\
\hline 0.611 & 0.373 & & 0.369 & 0,634 & 0.611 & \\
\hline \multicolumn{7}{|l|}{ ANOVA-1 } \\
\hline & Sum of sq & & df & Mean Square & $\mathbf{F}$ & $\mathbf{p}$ \\
\hline Regression & & & 1 & 44.064 & 109.391 & $.000^{\mathrm{b}}$ \\
\hline Residual & & & 198 & 0.43 & & \\
\hline Total & & & 199 & & & \\
\hline
\end{tabular}

Independent Variable: The Coach-Athlete Relationship; Dependent Variable: Athlete's Passion

According to the results of the regression analysis presented in the Table 6, the coach-athlete relationship has a statistically significant $(\mathrm{F}: 109.391 ; \mathrm{p}<0.05)$ positive $(\beta=0.611)$ effect on the variable of the passion for sports. Within the framework of the model, the coach-athlete relationship variable describes the athlete's passion variable at a percentage of $36.9 \%$ (adjusted $\mathrm{R}$ square). In other words, $36.9 \%$ of the total variance related to athlete's relationship passion is described with the coach-athlete relationship. The regression analysis showed that, the coach-athlete relationship is an important predictor of the variable of passion for sports. 


\section{Discussion and Conclusion}

All the hypotheses we produced in the beginning of our research, have been accepted. There is a positive relationship between the coach-athlete relationship and its sub-dimensions of commitment, closeness and complementarity and the passion for sports, and its sub-dimensions of harmonious passion, obsessive passion. Besides, the regression analysis has shown that the coach-athlete relationship has a relatively high impact on the passion for sports. In other words, as the effectiveness and quality of the coach-athlete relationship increase, so does "passion", which is one of the most important motivation sources for the athletes.

At the end of our research it was found that, the coach-athlete relationship was at high level. Analysis of the sub-dimensions revealed out that, the highest agreement was with the sub-dimension of commitment, then with the sub-dimension of closeness, and finally with the sub-dimension of complementarity. It can be concluded that, the most explicit desire of the handball players participating in our research was to continue working together.

In the study where Rhind et al., (2012) compared the coach-athlete relationship of individuals and team players, they reported that, while individual athletes paid more importance to their relationship with the coach and the scores of the team players were also close to that. Hagan Jnr. et al., (2017) pointed out in their study that, coaches acted in a democratic manner at the rate of 59\%, they acted in autocratic manner at the rate of $43 \%$ and during a race they provided social support and positive feedback at the rate of 50\%. In some researches performed on team players. It was found that, unlike the individual athletes, team players preferred autocratic coaches (Baker et al., 2003). At the end of their research Fry \& Gano-Overway (2010) pointed out that, the coach also helped the athletes develop their social and psychological competencies. On the other hand, the age and the year of sportsmanship did not make a significant difference on the coach-athlete relationship but Kolayiş \& Çelik (2018) mentioned a negative relationship between age and coach-athlete relationship.

The passion for sports was found to be relatively high, indeed. The scores obtained from harmonious passion was higher than the scores obtained from obsessive passion. It can be concluded that the handball players in our research group are doing this sport with self-motivation in general, without external factors or pressure.

De La Vega et al., (2016) found in their research that, harmonious and obsessive passion scores of team players were higher than the scores of individual athletes. Furthermore, according to the research of Vallerand et al., (2003), team players have higher harmonious passion scores than the individual athletes. In a team, the athletes' perceived role and responsibilities can be more obvious. Winning and congratulating and cooperation and a good coordination can be directly related with harmonious passion.

Moreover; the coach-athlete relationship was found to be the most important predictor of the athletes' passion for sports. Clubs should take necessary measures about this issue and employ coaches that will understand, establish good and appropriate relationship and work in harmony with the athletes. They should also try to improve these features of the current coaches.

In our research, the rates of agreement with the coach-athlete relationship and its sub-dimensions and athlete's passion and its sub-dimensions did not change depending on demographic features like the age of the athletes or the time period they have been playing handball for. This finding was consistent with some literature studies and inconsistent with some others. In their research intended for the determination of the Communication Skills in Individual and Team Players and their Level of Communication with the Coach, Karademir \& Türkçapar (2016) reported that, players who had been working with the same coach for a long time period had the highest level of agreement. In the same research, female athletes had the highest level of agreement. Athletes with longer experience in active sports life had the highest level of agreement. The results of the research conducted by Yücel (2010) on wrestlers in order to assess the coach-athlete relationship, were similar to ours. Sex and the time period the athlete has been holding a certificate for, creates no significant difference on the levels of the coach-athlete relationship.

According to the research conducted by Kassin \& Infante (1999) on 192 male high-school student athletes in order to analyse the aggressive communication in the coach-athlete relationship; coaches with more aggressive communication style were perceived as less positive in terms of communication and consequently, athletes displayed less fair-play, they were less content with their coaches and less successful with respect to the 'win-don't lose' percentage. These findings are consistent with certain researches (like Gould, Hodge, Peterson \& Giannini, 1989; Smith \& Smoll, 1990) analysing the preferences of the coaches and athletes regarding positive feedback.

As a result, there is a relationship between coach-athlete relationship and sport passion. Also coach-athlete relationship effects on sport passion. It is suggested that a research is performed on both the individual athletes and on team players by adding different variables. 


\section{References}

Adie, J. W., \& Jowett, S. (2010). Meta-perceptions of the coach-athlete relationship, achievement goals, and intrinsic motivation among sport participants. Journal of Applied Social Psychology, 2750-2773. https://doi.org/10.1111/j.1559-1816.2010.00679.x

Altıntaş, A., Çetinkalp, Z., \& Aş̧̧ı, H. (2012). Antrenör-sporcu ilişkisinin değerledirilmesi: geçerlik ve güvenirlik çalışması. Hacettepe Spor Bilimleri Dergisi. 23(3), 119-128.

Amorose, A. J., \& Anderson-Butcher, D. (2007). Autonomy-supportive coaching and self-determined motivation in high school and college athletes: A test of self-determination theory. Psychology of Sport and Exercise, 8, 654-70. https://doi.org/10.1016/j.psychsport.2006.11.003

Arıpınar, E., \& Donuk, B. (2011). Spor yönetim ve organizasyonlarinda etik yaklaşimlar fairplay. Ötüken Neşriyat A.Ş. İstanbul.

Ashley, E. S., \& Gretchen, A. K. (2009) Abused athletes' perceptions of the coach-athlete relationship, Sport in Society, 12(2), 227-239. https://doi.org/10.1080/17430430802591019

Baker, J., Yardley, J., \& Cote, J. (2003). And individual sports. Int. J. Sport Psychol, 34, 226-239.

Black, S. J., \& Weiss, M. R. (1992). The relationship among perceived coaching behaviors, perception of ability, and motivation in competitive age-group swimmers. Journal of Sport and Exercise Psychology, 14, 309-325. https://doi.org/10.1123/jsep.14.3.309

Çalışkan, G. (2011). Karizmatik antrenör algısının futbolcularda antrenör-sporcu ilişkisi, sporcu doyumu, takım birlikteliği ve takım bağlılığına etkileri. Doktora Tezi. Gazi Üniversitesi,, Sağlık Bilimleri Enstitüsü, Ankara.

Caliskan, G. (2015). An examination of coach and player relationships according to the adapted $\operatorname{lmx} 7$ scale: a validity and reliability study, Measurement in Physical Education and Exercise Science, 19(1), 22-33. https://doi.org/10.1080/1091367X.2014.977996

Cumming, S. P., Smoll, F. L., Smith, R. E., \& Grossbard, J. R. (2007). Is winning everything? The relative contributions of motivational climate and won-lost percentage in youth sport. Journal of Applied Sport Psychology, 19, 322-336. https://doi.org/10.1080/10413200701342640

De La Vega, R., Parastatidou, I. S., Ruíz-Barquín, R., \& Szabo, A. (2016). Exercise addiction in athletes and leisure exercisers: the moderating role of passion. Journal of behavioral addictions, 5(2), 325-331. https://doi.org/10.1556/2006.5.2016.043

Demirci, E., \& Çepikkurt, F. (2018). Examination of the relationship between passion, perfectionism and burnout in athletes. Universal Journal of Educational Research, 6(6), 1252-1259. https://doi.org/10.13189/ujer.2018.060616

Donuk, B. (2007). Liderlik ve Spor. Ötüken Neşriyat A.Ş. İstanbul.

Filiz, B., \& Demirhan, G. (2017). Antrenörlük davranışı değerlendirme ölçeği’nin türk kültürüne uyarlanması. Spormetre. 15 (1):1-10.

Fry, M. D., \& Gano-Overway, L. A. (2010). Exploring the contribution of the caring climate to the youth sport experience. Journal of applied sport psychology, 22(3), 294-304. https://doi.org/10.1080/10413201003776352

Fry, M. D., \& Newton, M. (2003). Application of achievement goal theory in an urban youth tennis setting. Journal of Applied Sport Psychology, 15, 50-66. https://doi.org/10.1080/10413200305399

Gould, D., Hodge, K., Peterson, K., \& Giannini, J. (1989).An exploratory examination of strategies used by elite coaches to enhance self-efficacy in athletes. Journal of Sportand Exercise Psychology, 11, 128-140. https://doi.org/10.1123/jsep.11.2.128

Göksel, A. G., Caz, Ç., Yazıcı, Ö. F., \& Pala, A. (2016). Spor lisesi öğrencilerinin iletişim becerilerinin bazı değişkenlere göre incelenmesi. Uluslararası Sosyal Araştırmalar Dergisi, 9(44), 1440-1445.

Gustafsson, H., Hassme, N., P., \& Hassme, N. N. (2011). Are athletes burning out with passion? European Journal of Sport Science, 11(6), 387-395. https://doi.org/10.1080/17461391.2010.536573

Güllü, S., \& Şahin, S. (2016). The analysis of revenge behaviours of trainers based on certian variables (Antrenörlerin intikam-öç alma davranışlarının bazı değişkenler açısından incelenmesi. The Journal of International Social Research (Uluslararası Sosyal Araştırmalar Dergisi), 9(47), 863-871. https://doi.org/10.17719/jisr.2016.1432

Hagan, Jr, J. E., Ansah, E. W., Pollmann, D., \& Schack, T. (2017). Elite student-athletes' perceptions of coaches' behavior during the 23rd world universiade games in Kazan, Russia. International Journal of Human Movement 
and Sports Sciences, 5(4), 68-76. https://doi.org/10.13189/saj.2017.050402

Hollembeak, J., \& Amorose, A. J. (2005). Perceived coaching behaviors and college athletes' intrinsic motivation: A test of self-determination theory. Journal of Applied Sport Psychology, 17, 20-36. https://doi.org/10.1080/10413200590907540

Horn, T. S. (1985). Coaches' feedback and changes in children's perceptions of their physical competence. Journal of Educational Psychology, 77, 174-186. https://doi.org/10.1037/0022-0663.77.2.174

Jowett, S. (2005). The coach-athlete partnership. The Psychologist. 18(7), 412-415.

Jowett, S. (2007). Interdependence analysis and the $3+1 \mathrm{Cs}$ in the coach-athlete relationship. In S. Jowett \& D. Lavallee (Eds.), Social psychology in sport (pp. 15-28). Champaign, IL: Human Kinetics.

Jowett, S. (2008). Moderator and mediator effects of the association between the quality of the coach-athlete relationship and athletes' physical self-concept. International Journal of Coaching Science, 2(1).

Jowett, S., \& Cockerill, I. M. (2002). Incompatibility in the coach-athlete relationship. In I.M. Cockerill (Ed.) Solutions in sport psychology (pp.16-31). London:Thomson Learning.

Jowett, S., \& Ntoumanis (2004). The coach-athlete relationship questionnaire (CART-Q): development and initial validation. Scandavian Journal of Medicine and Science in Sports. 24, 245-257. https://doi.org/10.1111/j.1600-0838.2003.00338.x

Jowett, S., Paull, G., Pensgaard, A. M., Hoegmo, P. M., \& Riise, H. (2005). Coach-athlete relationship. In J. Taylor \& G. S. Wilson (Eds.), Applying sport psychology: Four perspectives (pp. 153-170). Champaign, IL: Human Kinetics.

Karademir, T., \& Türkçapar, Ü. (2016). Bireysel ve takim sporcularinda iletişim becerilerinin incelenmesi. Atatürk Üniversitesi Spor Bilimleri Fakültesi, Beden Eğitimi ve Spor Bilimleri Dergisi. 18(4), 66-80.

Karakoç, Ö., Yüksek, S., Aydın, A. D., Karakoç, B., Yetiş, Ü., \& Baydil, B. (2011). Milli takım düzeyindeki erkek judocuların kulüp antrenörlerinde gözlemledikler etik dışı davranışlar. Kastamonu Eğitim Dergisi, 19(1), 321-332.

Kassing, J. W., \& Infante, D. A. (1999) Aggressive communication in the coach-athlete relationship, Communication Research Reports, 16, 2, 110-120. https://doi.org/10.1080/08824099909388708

Kelecek, S., \& Aşçı, H. (2013). Tutkunluk ölçeğinin üniversite sporcuları için geçerlilik ve güvenirlik çalışması. Türkiye Klinikleri. 5(2), 80-85.

Kolayiş, H., \& Çelik, N. (2018). Examining the relationship between coach-athlete relationship and sport participation motivation among athletes. 16th International Sport Sciences Congress. Antalya.

Kolayiş, H., Sarı, İ., \& Çelik, N. (2017). Parent-initiated motivational climate and self-determined motivation in youth sport: how should parents behave to keep their child in sport?. Kinesiology: International Journal of Fundamental and Applied Kinesiology, 49(2), 217-224. https://doi.org/10.26582/k.49.2.4

McLean, K. N., \& Mallett, C. J. (2012) What motivates the motivators? An examination of sports coaches, Physical Education \& Sport Pedagogy, 17, 1, 21-35. https://doi.org/10.1080/17408989.2010.535201

Paradis, K. F., Cooke, L. M., Martin, L. J., \& Hall, C. R. (2013). Too much of a good thing? Examining the relationship between passion for exercise and exercise dependence. Psychology of Sport and Exercise, 14, 493-500.

Pelletier, L. G., Fortier, M. S., \& Vallerand, R. J. N. M. (2002). Associations among perceived autonomy support, forms of self-regulation, and persistence: A prospective study. Motivation and Emotion, 25, 279-306. https://doi.org/10.1023/A:1014805132406

Rhind, D. J. A., Jowett, S., \& Yang, S. X. (2012). A comparison of athletes' perceptions of the coach-athlete relationship in team and individual sports. Journal of Sport Behavior, 35(4).

Şahin, M. (2011). Alp disiplini kayak antrenörlerinin çeşitli fiziksel ve fizyolojik parametrelerinin değerlendirilmesi. Uluslararası Hakemli Akademik Sosyal Bilimler Dergisi, 1(1), 108-113.

Sarrazin, P., Guillet, E., \& Cury, F. (2001). The effect of coach's task- and ego-involving climate on the changes in perceived competence, relatedness, and autonomy among girl handballers. European Journal of Sports Sciences, 1, 1-9. https://doi.org/10.1080/17461390100071404

Sarrizin, P., Vallerand, R. J., Guillet, E., Pelletier, L. G., \& Cury, F. (2002). Motivation and dropout in female https://doi.org/10.1002/ejsp.98

Short, S. E., \& Short, M. W. (2005). Essay Role of the coach in the coach-athlete relationship. Medicine and Sport, 366, 529-530. https://doi.org/10.1016/S0140-6736(05)67836-1 
Sinclair, D. A., \& Vealey, R. S. (1989). Effects of coaches' expectations and feedback on the self-perceptions of athletes. Journal of Sport Behavior, 12, 77-91.

Smith, R. E., \& Smoll, F. L. (1990). Self-esteem and children's reactions to youth sport coaching behaviors: A field study of self-enhancement processes. Developmental Psychology, 26, 987-993. https://doi.org/10.1037/0012-1649.26.6.987

Vallerand, R. J. (2008). On the psychology of passion: In search of what makes people's lives most worth living. Canadian Psychology, 49, 1-13. https://doi.org/10.1037/0708-5591.49.1.1

Vallerand, R. J., \& Houlfort, N. (2003). Passion at work: Toward a new conceptualization. In D. Skarlicki, S. Gilliland, \& D. Steiner (Eds.), Social issues in management (Vol. 3, pp. 175-204). Greenwich, CT: Information Age Publishing.

Vallerand, R. J., \& Losier, G. F. (1999). An integrative analysis of intrinsic and extrinsic motivation in sport. Journal of Applied Sport Psychology, 11, 142-69. https://doi.org/10.1080/10413209908402956

Vallerand, R. J., \& Miquelon, P. (2007). Passion for sport in athletes. In D.Lavalle'e \& S. Jowett (Eds.), Social psychology in sport (pp. 249-263). Champaign, IL: Human Kinetics.

Vallerand, R. J., Blanchard, C. M., Mageau, G. A., Koestner, R., Ratelle, C., Le'onard, M., et al. (2003). Les passions de l'âme: On obsessive and harmonious passion. Journal of Personality and Social Psychology, 85, 756-767. https://doi.org/10.1037/0022-3514.85.4.756

Vallerand, R. J., Ntoumanis, N., Philippe, F. L., Lavigne, G. L., Carbonneau, N., Bonneville, A., Lagacé-Labonté, C., \& Maliha, G. (2008). On passion and sports fans: A look at football, Journal of Sports Sciences, 26(12), 1279-1293. https://doi.org/10.1080/02640410802123185

Vallerand, R.J., \& F.L. Rousseau (2001). Intrinsic and extrinsic motivation in sport and exercise: A review using the hierarchical model of intrinsic and extrinsic motivation. In Hand book of sport psychology, ed. R.N. Singer, H.A. Hausenblas and C.M. Janelle, 389-416. New York: Wiley

Voss, T. (2000). Lider Yöneticilik, (Çeviren: Mehmet Zaman), İstanbul:Hayat Yayınevi.

Weinstein, M. D., Smith, M. D., \& Weisenthal, D. L. (1995). Masculinity and hockey violence. Sex Roles, 33, 831-847. https://doi.org/10.1007/BF01544782

Yaşar, O. M., \& Sunay, H. (2018). Futbol antrenörlerinin iş doyumlarinin ve örgütsel bağliliklarinin incelenmesi. Journal of Human Sciences, 15(2), 952-969. https://doi.org/10.14687/jhs.v15i2.5239

Yildiz, S.M. (2011): Relationship between leader-member exchange and burnout in professional footballers, Journal of Sports Sciences, 29(14), 1493-1502. https://doi.org/10.1080/02640414.2011.605165

Yücel, M. G. (2010). Antrenör-sporcu ilişkisini etkileyen faktörler (güreş örneği). Yüksek Lisans Tezi. Gazi Üniversitesi, Sağlık Bilimleri Enstitüsü, Ankara.

\section{Copyrights}

Copyright for this article is retained by the author(s), with first publication rights granted to the journal.

This is an open-access article distributed under the terms and conditions of the Creative Commons Attribution license which permits unrestricted use, distribution, and reproduction in any medium, provided the original work is properly cited. 